\title{
Neolityczne megality Nałęczowa - debiut budownictwa na Lubelszczyźnie
}

\author{
Natalia Przesmycka \\ Lucjan Gazda \\ Katedra Geotechniki, Wydziat Budownictwa i Architektury
}

Katedra Architektury, Urbanistyki i Planowania Przestrzennego, Wydział Budownictwa i Architektury

\begin{abstract}
Streszczenie: Znaleziska archeologiczne silnie pobudzały wyobraźnię, zwłaszcza w okresie przełomu XIX i XX wieku, gdy w architekturze europejskiej poszukiwano stylów narodowych odnosząc się do źródeł lokalnej tożsamości. Celem artykułu jest omówienie megalitycznych grobowców odkrytych przez Henryka Wiercińskiego na początku XX wieku w okolicach Nałęczowa, pod kątem analizy myśli inżynierskiej przyświecającej ich konstrukcji, oraz możliwego wpływu znaleziska na architekturę Nałęczowa w pierwszych dekadach XX wieku.
\end{abstract}

Słowa kluczowe: megality, Nałęczów, lokalne surowce kamienne, początki budownictwa

\section{Wstęp}

Trwałe, wielosezonowe przebywanie człowieka na Płaskowyżu Nałęczowskim, a co za tym idzie pierwsze obiekty budowlane z tym związane można wiązać dopiero z neolitem. Panujący wcześniej klimat i brak naturalnych, o odpowiednim komforcie termicznym obiektów typu jaskiń oraz sposób prowadzonej gospodarki wykluczały taką możliwość, co potwierdzają dotychczasowe badania archeologiczne (Hensel 1980, Jażdżewski 1981). Rewolucyjnymi w tym kontekście wydają się megalityczne obiekty kamienne (Ryc. 1) odkryte na początku XX wieku w okolicach Nałęczowa (Wiercieński 1903, 1905).

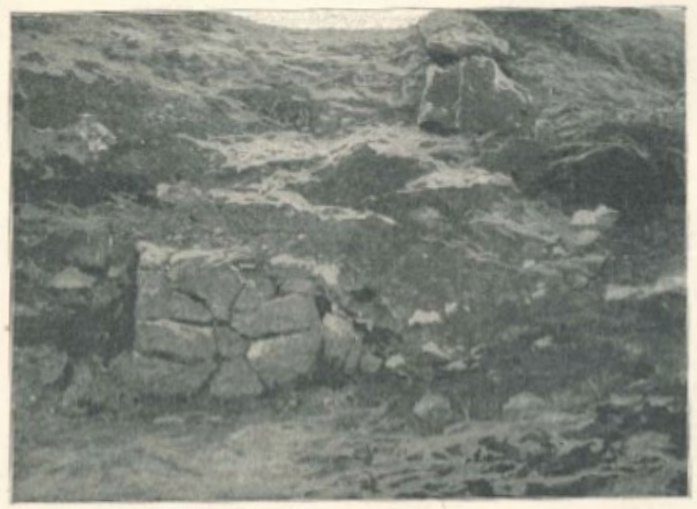

OROBY PRZEDHISTORYCZNE POD NALECCZOWEM

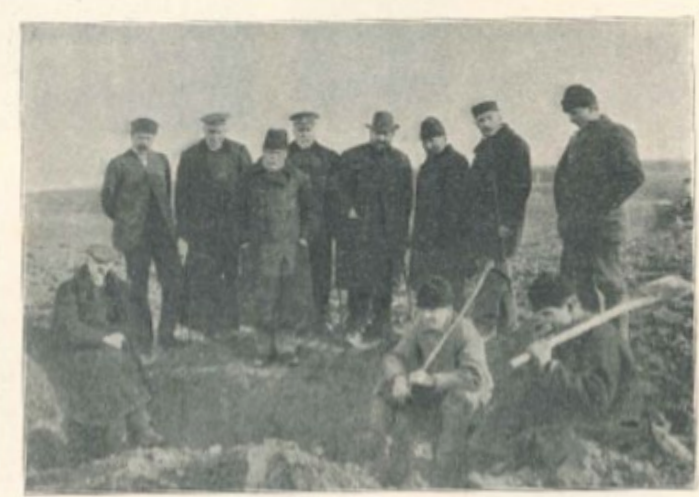

ROZKOPYWANIE GROBÓW PRZEDHISTORYCZNYCH NA ANTOPOLU 7 IN I903

Ryc. 1. Odkopane megality i ich eksplotarzy na fotografiach z epoki (Wiercieński 1903). 
Jest to bez wątpienia pierwsze na lessowym Płaskowyżu Nałęczowskim, a być może na całej Lubelszczyźnie inżynierskie potraktowanie lokalnego kamienia, czego efektem było dzieło dla ówczesnych o znaczeniu symbolicznym, a dla współczesnych bez wątpienia dziełem budowlano-architektonicznym (Gazda, Kwiatkowski 2017). Wydaje się, że omówienie tej eksplozji myśli inżynierskiej jest rzeczą oczywistą i ważną dla poznania historii budownictwa i architektury Lubelszczyzny. Szczególnie, że efektowność i unikatowość tego epizodu nie została dostrzeżona w nowszej literaturze oraz nie podjęto w tym rejonie badań metodami współczesnej archeologii.

\section{Faktografia}

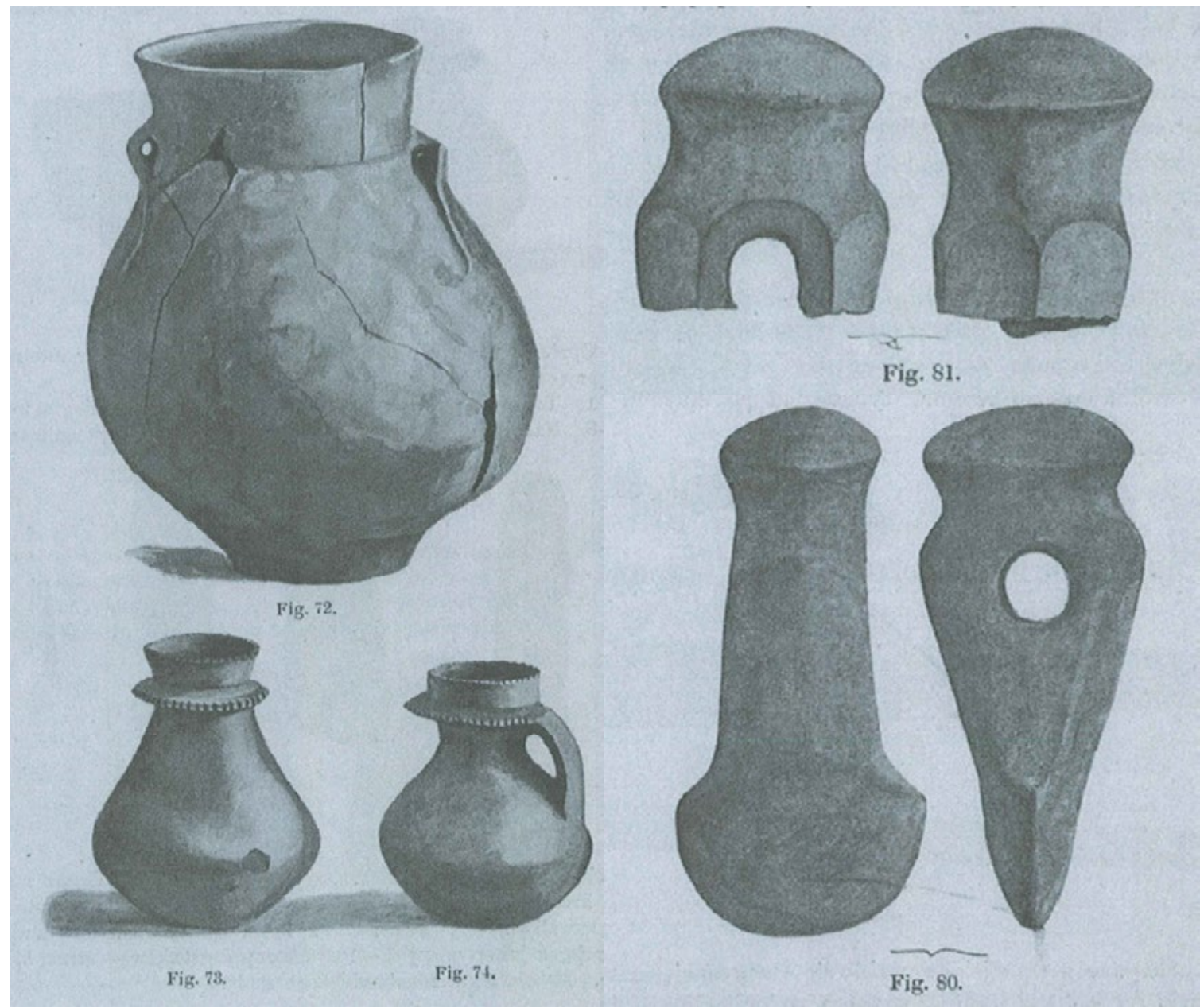

Ryc. 2. Ceramika i topory kamienne (sjenitowe) z eksplorowanych kurhanów (Wiercieński 1905).

Informacja o występowaniu neolitycznych (w oryginale "kamienia szlifowanego") stanowisk archeologicznych w okolicach Nałęczowa ukazała się po raz pierwszy w 1903 roku w formie popularnego artykułu (Wiercieński 1903) i w wersji nieco zmienionej została powtórzona w specjalistycznym czasopiśmie Światowit (Wiercieński 1905). Jak na prace archeologiczne z początku XX wieku należy je uznać za dobrze udokumentowane, z liczną dokumentacją fotograficzną i rysunkową. Znalezisko artefaktów i obiektów grobowych miało charakter przypadkowy w trakcie "szosowania” drogi między zakładem leczniczym a stacją kolejową Nałęczów (w tym okresie Sadurki). Ekonomika przedsięwzięcia wskazywała na jak najbliższy transport materiałów kamiennych i źródłem takim okazało się cmentarzysko o charakterze kurhanu, wykonane w znacznej części z lokalnych skał określanych jako „siwak". Jest to skała paleogeńska typu wapienia lub gezy. Skały te występują w formie wychodni 
w erozyjnych skarpach i przełomach doliny Bystrej i Bochotniczanki. Były one eksploatowane do czasów nowożytnych (Gazda, Gazda 2005) i utrwalone są w lokalnym budownictwie (Gazda 2017). Z rejonu stanowiska wywieziono kilkanaście fur kawałków skalnych tworzących pod cienką $(20-25 \mathrm{~cm})$ pokrywą glebową, nieregularną elipsę o promieniu 7-9 m. Dopiero znalezienie toporka kamiennego i właściwa ocena wagi znaleziska przez właściciela majątku Antopol, pana Stanisława Śliwińskiego wstrzymały eksploatację tego stanowiska. Modne w tym czasie zainteresowanie "starożytnościami” przywiodło tu miejscowych archeologów, dr Olechnowicza i prof. Łopacińskiego z Lublina, a kontynuował poszukiwania i badania dr Malewski z Nałęczowa. Na podstawie artefaktów kamiennych i ceramicznych (Ryc. 2) stanowisko to należy wiązać z neolityczną kulturą pucharów lejkowatych (IV tysiąclecie przed Chrystusem).

Ceramika wykonywana jeszcze bez uzycia koła garncarskiego oraz precyzja wykonania kamiennych toporów świadczą o dużym zmyśle technologicznym, inżynierskim i estetycznym człowieka z kręgu kultury pucharów lejkowatych, mieszkańca tej ziemi i twórcy megalitów 5-6 tysięcy lat temu.

\section{Lokalizacja}

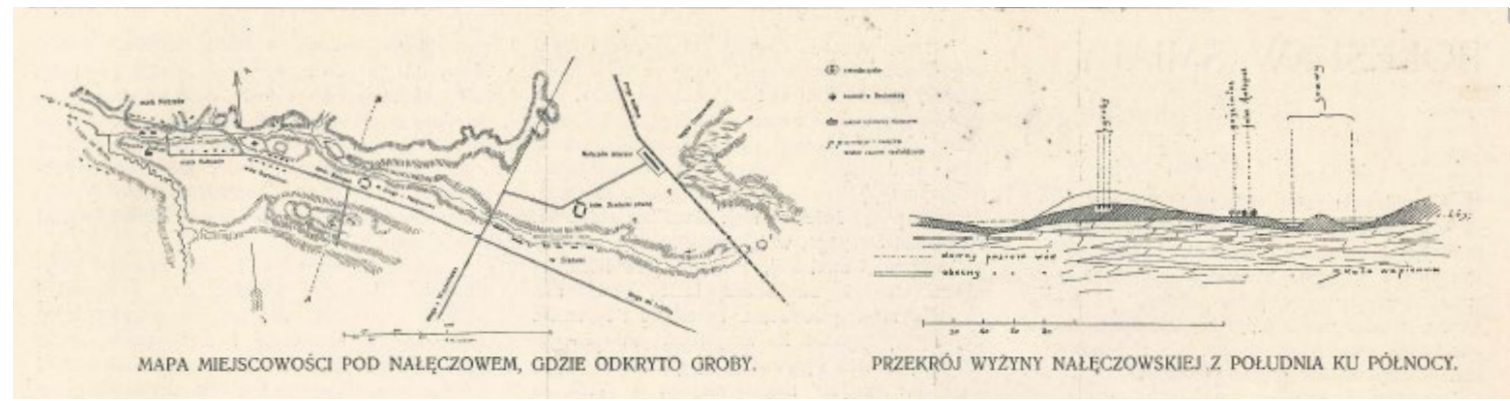

Ryc. 3. Lokalizacja i dokumentacja badań megalitów załączona w Tygodniku llustrowanym z 1903 roku (Wiercieński 1903).

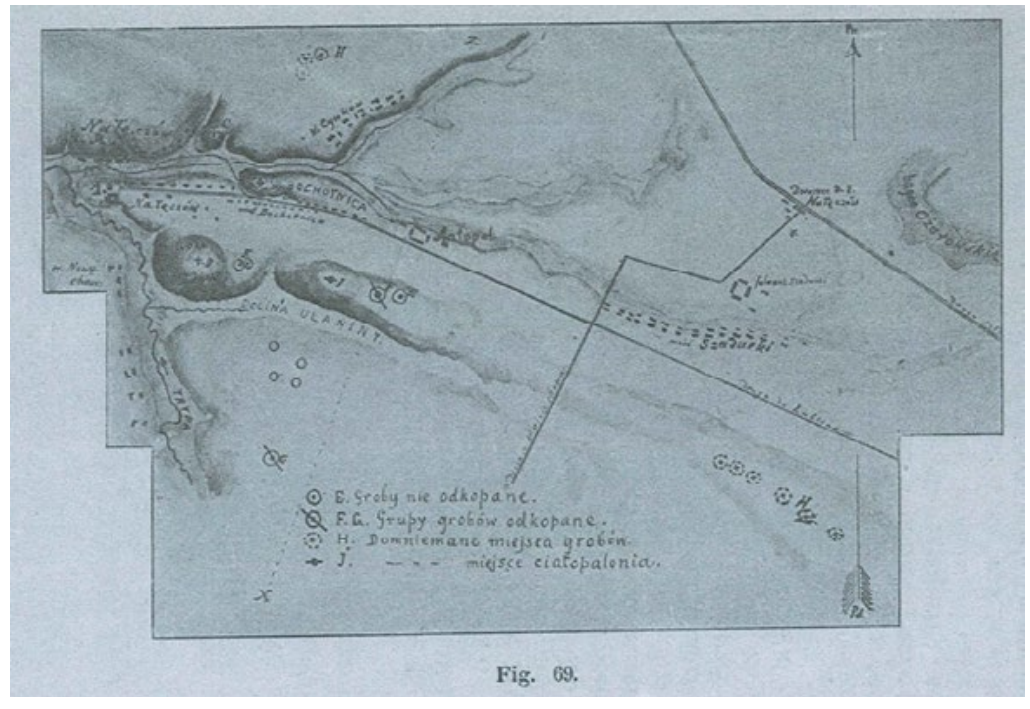

Ryc. 4. Lokalizacja i dokumentacja badań megalitów załączona w czasopiśmie Światowit z 1905 roku (Wiercieński 1905).

Stanowiska archeologiczne z megalitami są znaczone powierzchniowym występowaniem białego rumoszu skalnego, spalenizny oraz ceramiką lokalizowanych wzdłuż wyraźnej elewacji morfologicznej, równoległej do prawobrzeżnej doliny Bochotniczanki (Ryc. 3 i 4) między Sadurkami i Nałęczowem oraz na garbie morfologicznym na południe od Bochotniczanki. Obejmują one grunty Bochotnicy, Cynkowa, Strzelec i Sadurek. Rozmieszczenie tych stanowisk jest generalnie zbieżne z kierunkami urbanizacji tych terenów w wiekach średnich i współczesnych. Oddalone są od osi zabudowy współczesnego Nałeczowa o ok. 0,2-0,5 km. Należy wnosić, że o ile te 
nekropolie związane były z trwałym pobytem neolitycznych kultur w tym rejonie, to ślady obiektów mieszkalnych i gospodarskich mogły ulec zniszczeniu w ramach młodszych, do współczesnych włącznie, faz rozwoju Bochotnicy i Nałęczowa. Mimo istnienia powierzchniowych znalezisk ceramiki, krzemiennych i kamiennych zabytków w dużych nagromadzeniach, mogących świadczyć o siedliskach neolitycznych, brak badań archeologicznych nie pozwala jednoznacznie wiązać ich z siedzibami oraz ich związków czasowo-przestrzennych z kurhanami. Najbardziej efektowne megality miały charakter orientowanych wschód-zachód grobów (Ryc. 5) w obstawie białych kamieni i przykryte były wspólnym nasypem/brukiem z białych, miejscowych kamieni (Ryc. 6) o charakterze kurhanu.

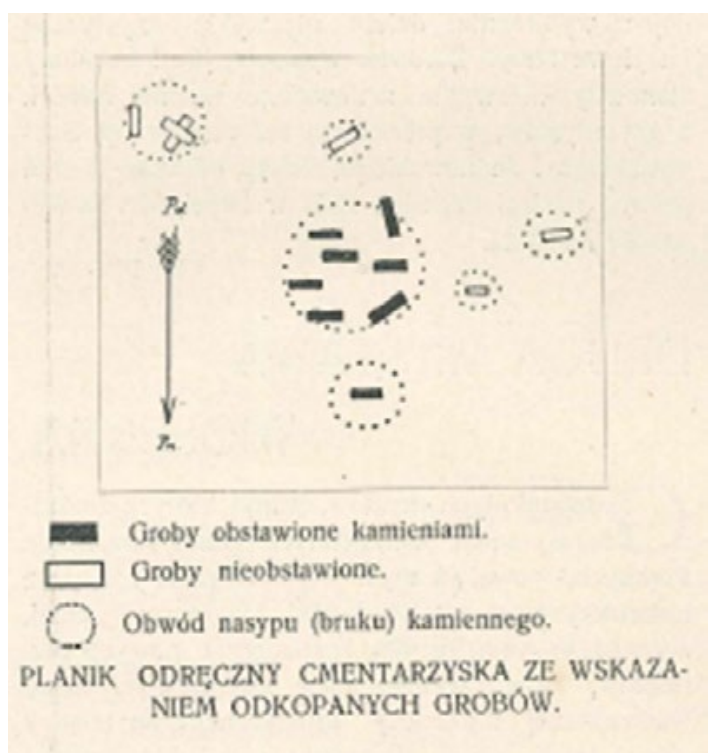

Ryc. 5. Sytuacja i orientacja grobów megalitycznych załączona w Tygodniku llustrowanym z 1903 roku (Wiercieński 1903).

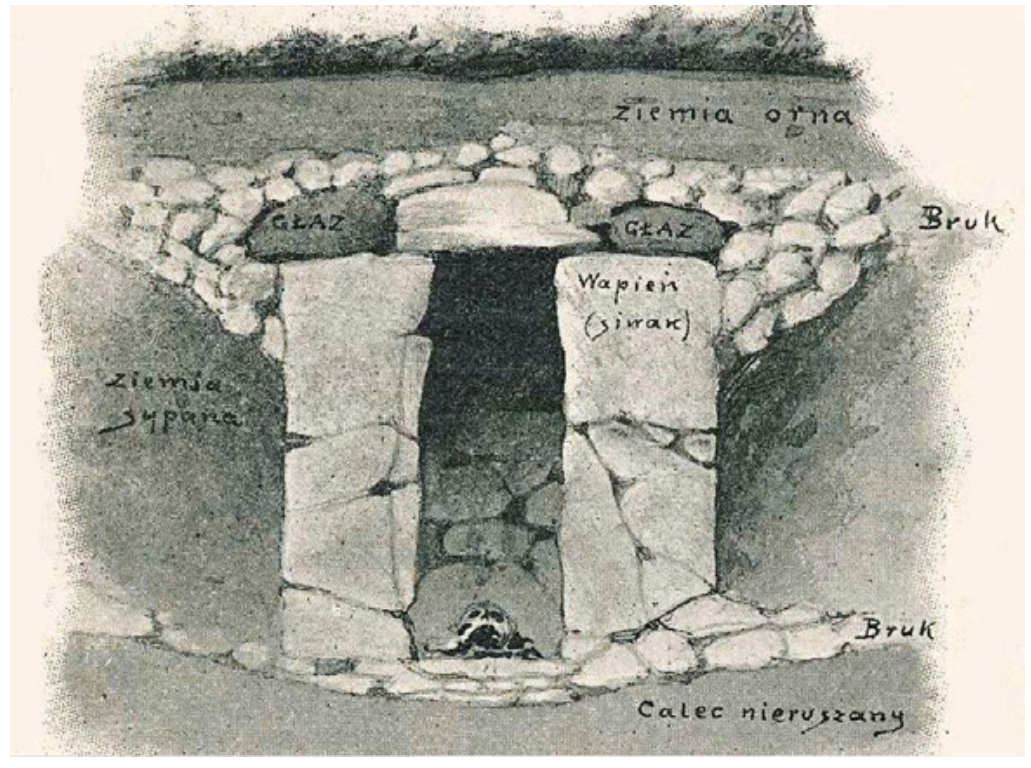

Ryc. 6. Przekrój poprzeczny jednego z grobów megalitycznych załączony w Tygodniku llustrowanym z 1903 roku (Wiercieński 1903).

W rejonie tym udokumentowano także dwa groby o innej orientacji oraz kilka grobów bez obstawy kamiennej, wyłącznie przykryte rumoszem skalnym. Brak szczegółowych badań i opisów wyklucza możliwość określenia stratygrafii tych obiektów, jednolitości kulturowej i czasowej, itp. Łącznie w rejonie tym (Ryc. 5) udokumentowano 13 grobów, osiem w obudowie kamiennej i pięć ziemnych. Kilka grobów (3-4) uległa całkowitemu zniszczeniu przed przystąpieniem do badań, w wyniku wyrabowania na cele budowy drogi. 


\section{Konstrukcja i architektura megalitu}

Megality, ale także groby ziemne pokryte są od powierzchni warstwą ściśle dopasowanych białych kamieni, tworzących bruk (Ryc. 6) o grubości 15-20 cm (Ryc. 7), tworząc w pierwotnej morfologii formę niskiego, kamiennego kurhanu. W czasie badań powierzchnia ta była pokryta 20-30 centymetrową warstwą deluwiów glebowych.

a)

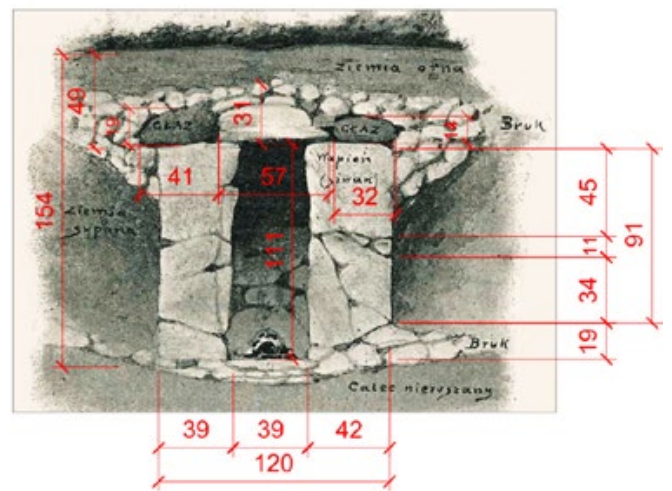

b)

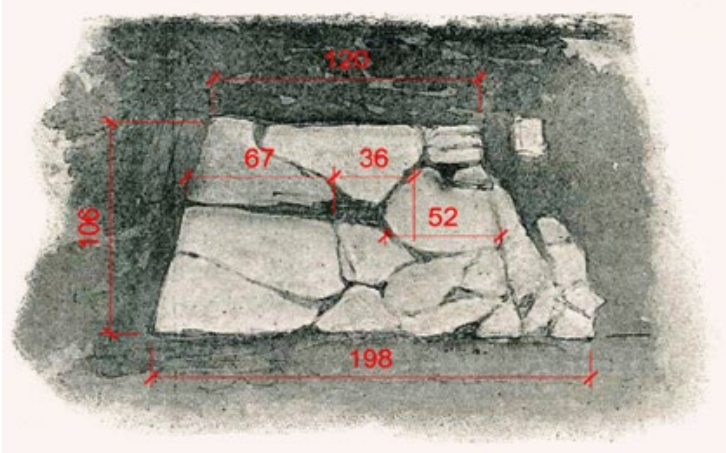

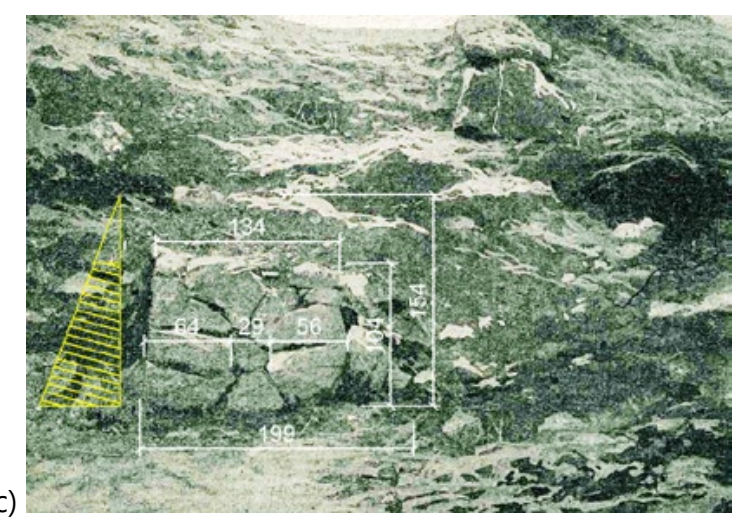

Ryc. 7. Archiwalna fotografia i rzuty megalitu (Wiercieński 1903) z naniesionymi wymiarami, zgodnie z opisem w artykule; a-b) rzuty c) fotografia [cm]

Zamieszczone na rysunku 7.a-b wymiarowanie wprowadzone na podstawie wartości liczbowych podanych w centymetrach w artykule, świadczy o precyzji wykonywanych szkiców i w konsekwencji zgodności co do wymiarów elementów. Wymiary ze szkiców odpowiadają tym z fotografii 7.c.

Ściany grobów wykonano z kamienia wapiennego „siwaka”, który jest bardzo podatny na zmienne oddziaływania środowiskowe. Konstrukcja/kamień trwając w ustalonych warunkach wilgotnościowo-temperaturowych pod gruntem przetrwała milenia. Odsłonięcie ścian mogło spowodować szybki proces wietrzenia i w konsekwencji destrukcję budowli. Bez wątpienia stabilność stanu obciążeń, czyli ciężarów własnych oraz parcia bocznego gruntu w bardzo długim czasie wytworzyła rodzaj współpracy, który obecnie określa się jako konstrukcję zintegrowaną, w tym przypadku ściana - grunt. Odsłonięcie ścian wejściowej i boczne naruszyło istniejący stan równowagi. Na rysunku 7.c schematycznie zaznaczono, kolor żółty, parcie boczne na ścianę z uwzględnieniem górnego nasypu. Dodatkowo, bardzo korzystna proporcja wymiarów (szerokości ściany) / (wysokości ściany), równa w przybliżeniu $1 / 2$ jest miarą smukłości, a dokładniej odwrotności smukłości czyli masywności ścian. Jednakże, jak widać na rysunkach 7.a-b, styki między kamieniami budującymi ściany tworzą liczne powierzchnie poślizgów lub tylko przegubów. Wietrzenie kamienia, struktura przegubowa, niesymetryczne parcie gruntu mogły być przyczynami zniszczenia grobu kamiennego.

Groby w obstawie kamiennej maja charakter skrzyni. Z układu gruntów należy wnosić, że były wykonywane w wykopie o głębokości ok. $1 \mathrm{~m}$. Dno wykopu wyłożono w dwóch-trzech warstwach płasko łupanych kamieni (siwaka) lub na warstwie drobnego rumoszu skalnego układane były płaskie płyty. Warstwy te stanowiły stabilizację mechaniczną podłoża lessowego oraz równocześnie posadzkę megalitu. Na warstwie tej ustawiano jeden obok drugiego . Konstrukcję stropu dodatkowo wzmacniał i uszczelniał bruk z białych lokalnych skał. 
W takim ujęciu rozwiązania 0.4-0,5 m grubości i około $1 \mathrm{~m}$ wysokości, lub ustawiano starannie dopasowane 2-3 bloki do pożądanej wysokości. Elementy te tworzyły ściany podłużne megalitu, o łącznej długości ok. $2 \mathrm{~m}$. Monolity, a także mniejsze bloki konstrukcyjne, geometrycznie były efektem ciosu wychodni lokalnych skał, ale także były częściowo ociosywane i formowane. Ściany zamykające skrzynkę megalitu z tyłu i przodu wykonane były z mniejszych płyt ustawianych pionowo wzdłuż dłuższych osi. Konstrukcję skrzyni pokrywały płaskie bloki stawiane nie płasko, lecz na sztorc w formie żebrowania, co pozwalało na uzyskiwanie większej wytrzymałości stropu megalitu. Na pionowych słupach konstrukcję stropu ryglowały głazy narzutowe ze skał krystalicznych o wielkości do 40-50 cm i przypuszczalnej wadze 40-60 Kg. Głazów tych było 4 do 6 na jednym grobie, czasami dodatkowo jeszcze były umieszczane na niektórych megalitach w części środkowej stropu. Całość konstrukcji wzmacniana była przez zasypanie gruntem przestrzeni między ściana boczną o krawędzią wykopu. Konstrukcję stropu dodatkowo wzmacniał i uszczelniał częściowo bruk wykonany z białych lokalnych skał. W takim ujęciu rozwiązania megalitu należy uznać, że głazy narzutowe nie pełniły tu roli symbolicznej, ew. ozdoby architektonicznej a przemyślany element wzmocnienia konstrukcji. Chociaż symboliki tych głazów nie można całkowicie wykluczyć, mając na uwadze jak istotną rolę odgrywały one w życiu ówczesnych (Ryc. 2). Brak opisu petrograficznego tych obiektów nie pozwala na wnikliwszą analizę intencji budowniczych megalitów. Wykorzystanie tych głazów musiało być znacznym wysiłkiem logistycznym, gdyż odpowiednio zasobne w te surowce są pozbawione pokrywy lessowej równiny polodowcowe Niziny Lubartowskiej i Równiny Bełżyckiej, co wymagało transportu z odległości kilku - kilkunastu kilometrów. Dociążały one pionowe osie megalitu oraz ryglowały swoją masą Iżejszy "siwak" tworzący strop skrzyni. Całość konstrukcji była na tyle stateczna i wytrzymała, że w warunkach geodynamicznych lekko nachylonego zbocza, w strefie aktywnej infiltracji i przemarzania przetrwała ok. 5 tys. Lat. Dopiero nadmierne odsłonięcie i eksploracja odkrywców spowodowało awarię i zniszczenie kilku obiektów. A jak można wyczytać w opisach (Wiercieński 1905) zamierzeniem badaczy i miejscowego właściciela ziemskiego było zadaszenie i eksponowanie tych megalitów.

\section{Analiza i wnioski}

Tradycja grobów megalitycznych wyrosła z przekonania o odradzaniu zmarłych przodków w celowo konstruowanych jaskiniach, odnoszących się do paleolitycznej preegzystencji w kamieniu (Kempiński 1993). Megalityczne kurhany z wewnętrznym grobowcem symbolizowały brzemienną Matkę Ziemię jako Tellus mater w odróżnieniu od Petra genitrix utożsamianej w jaskiniach człowieka paleolitycznego (Kowalik 2004). Megalityczne grobowce stawały się mieszkaniami dla zmarłych i symbolem odrodzenia, a użyty do ich budowy kamień stanowić miał o ich niezniszczalności i sakralnej waloryzacji. Megality lokalizowano poza osiedlami i domostwami. Ideologicznie w takim duchu megality w rejonie Nałeczowa. Mała dostępność dobrej jakości surowca skalnego zmuszała ówczesnych do eksperymentowania z lokalna miękką i lekką skała paleocenu, petrograficznie gezą zwaną regionalnie "siwakiem". Skały te mają niską i zmienną wytrzymałość na ściskanie w zakresie 5-15 MPa (lit), są silnie porowate, nasiąkliwe i niecałkowicie mrozoodporne. Technologicznie charakteryzują się małą blocznością. W tym kontekście należy wnioskować o dużym wyczuciu właściwości tych skał przez ówczesnych budowniczych. Dobór obróbka, dopasowanie i orientacja bloków w polu naprężeń realizowanych megalitów świadczą o dużym zmyśle inżynierskim i wrażliwości estetycznej. Megality nałęczowskie można uznać za pierwsze zaawansowane działania architektoniczno-budowlane na Lubelszczyźnie, a z całą pewnością za działania z użyciem lokalnych skał paleoceńskich. Eksploatacja kurhanów w początku XX wieku na potrzeby budowy lokalnej drogi i eksploracja megalitów doprowadziły do częściowej likwidacji tych obiektów. Na wpół amatorskie badania archeologiczne, odsłaniające neolityczne megality wzbudzały podziw odkrywców i lokalnych społeczności oraz zostały nagłośnione w ówczesnych mediach ogólnokrajowych. Pomysł zabezpieczenia obiektów i udostępnienie dla ogółu w formie zadaszonego pawilonu można uznać za jedne z pierwszych pomysłów i działań o charakterze konserwatorsko-udostępniającym zabytki z tak odległej przeszłości. Jednak stan wiedzy i technik eksploracji nie pozwolił na realizację tych śmiałych pomysłów. Odsłonięte i niezabezpieczone obiekty szybko uległy destrukcji. Jedynie zabytki ruchome eksponowane początkowo były w lokalnym muzeum w Nałęczowie, później w Lublinie i Krakowie, a następnie rozproszone straciły spójność swojego przekazu. 
Kontynuację dokonań budowniczych kultury pucharów lejkowatych można obecnie śledzić w witrażowym wątku elewacji wykonywanych ze skał serii "siwaka” w Nałęczowie i okolicach (Ryc. 8a.) oraz echa kontynuacji architektonicznej wrażliwości można doszukiwać się w Mauzoleum Adama Żeromskiego (Ryc. 8b.).

a)

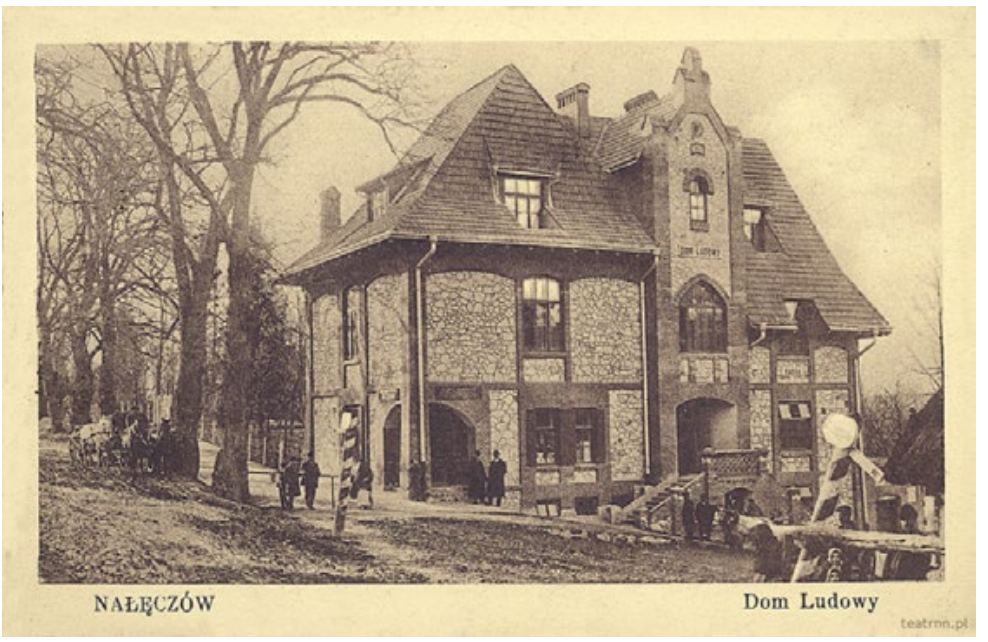

b)

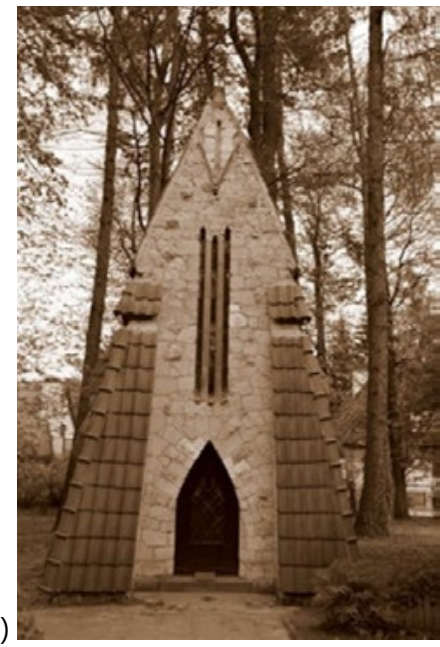

Ryc. 8. Witrażowy wątek wykonany z "siwaka" w formie płaskiej dzikówki w elewacji Domu Ludowego w Nałeczowie (a), mauzoleum Adama Żeromskiego w Nałęczowie (b).

Mauzoleum projektowali wspólnie Stefan Żeromski i Jan Koszyc Witkiewicz. Żeromski, pisarz i ojciec Adama, był najprawdopodobniej pomysłodawcą idei i formy. Architekt Witkiewicz dopracował projekt architektoniczny i wykonawczy. Bez wątpienia obaj, mieszkający lub często przebywający w tym czasie w Nałęczowie, musieli oglądać te megality oraz znali ich opisy, kontaktowali się z ich eksploratorami. Witkiewicz dodatkowo w tym czasie zajmował się inwentaryzacją i konserwacją zabytków starożytności, między innymi Wieży Ariańskiej w pobliskim Wojciechowie. Jego kontakty z miejscowymi intelektualistami i dziedzicem Antopola musiały zaowocować także myślą potrzeby ochrony tych obiektów. Jednak zazdrosna Tellus mater pochłonęła inżynierskie osiągnięcie człowieka neolitycznego realizującego tu na wysokim poziomie architektoniczno-budowlanym ideę pozostającej w jego świadomości i pamięci po przodkach ideę Petra genitrix. I wydaje się, że podobnie i także symbolicznie utrwalono w założeniach ideowych Mauzoleum Adama Żeromskiego przekaz megalitów pucharów lejkowatych z okolic Nałęczowa.

\section{Literatura}

[1] Hensel W. 1980. Polska starożytna. Ossolineum.

[2] Jażdżewski K. 1981. Pradzieje Europy środkowej. Ossolineum.

[3] Wiercieński H., 1903. Groby przedhistoryczne pod Nałęczowem. Tygodnik llustrowany nr 20 (2.273), 394-395.

[4] Wiercieński H., 1905. Groby kamienne ze szkieletami z epoki kamienia gładzonego, odkryte pod Nałęczowem w roku 1903. Światowit nr 6, 81-88.

[5] Gazda L., Gazda B., 2005. Górnictwo skalne Nałęczowa. Rozdział w monografii pod red. Z. Krzowskiego „Historia i współczesność górnictwa na terenie Lubelszczyzny". Wyd. Pol. Lubelskiej.

[6] Gazda L., Kwiatkowski B. 2017

[7] Gazda L., 2017. Regionalizm architektury i budownictwa z miękkich kamieni Lubelszczyzny - historyczny rozwój i współczesna unifikacja Wyd. Uczelniane Uniwersytetu Technologiczno-Przyrodniczego w Bydgoszczy (w druku).

[8] Kempiński A.M., 1993. Słownik mitologii ludów indoeuropejskich. Poznań.

[9] Kowalik A., 2004. Kosmologia dawnych Słowian. Kraków, 225. 